\title{
Margaret Wrong Memorial Fund: Awards for 1956
}

Trre Silver Medal was awarded to Mr. M. C. Mainza, of Northern Rhodesia, for his book in Tonga entitled Kabuca Uleta Tunji, published in 1956 by the University of London Press Ltd. in association with the Rhodesia and Nyasaland Joint Publications Bureau. The medal is to be presented in Lusaka.

The Margaret Wrong Prize of $£ 25$ was awarded to Mr. A. W. Kayper-Mensah, of Wesley College, Kumasi, Ghana, for a collection of poems in English, Light in Jungle Africa. A second prize of $f$ io was awarded to $\mathrm{Mr}$. Wole Soyinka for a novel in English, Oji River, and a third prize of $f 5$ to Mr. Asavia Wandira of Makerere College for an historical study: The Church Missionary Society in Busoga District, Uganda.

\section{Arts congolais de la Province de Léopoldville}

Du 7 au 26 d'Août (1956) eut lieu au Musée de la Vie Indigène, Léopoldville, une exposition d'arts congolais. Il y a un an, la province du Kasai avait organisé sa deuxième exposition biennale des arts à Luluabourg, téunissant les œuvres des $\mathrm{Ba}-\mathrm{Kuba}$ et des peuples apparentés. Suite au succès de cette initiative, le Gouverneur-Général a pris l'initiative d'étendre à toutes les provinces l'organisation de biennales d'art. L'exposition à Léopoldville a présenté, non seulement des œuvres produits en milieu coutumier, soustrait à toute influence directe de l'Europe, mais aussi des travaux réalisés dans les ateliers ou des écoles sous direction européenne. On constate que, dès le présent, l'art congolais en milieu coutumier connaît une époque de déclin, tandis que dans les centres extra-coutumiers comme Léopoldville et Matadi, les ateliers sous direction européenne enregistrent un certain progrès.

\section{Social Aspects of Industrialisation in Rural Areas in Africa}

Aт the request of the Social Sciences Division of UNESCO, and under the direction of the Research Office on the Social Implications of Technological Change, an inquiry has been carried out and a number of reports prepared on the social aspects of industrialization in rural areas in Africa. Each report contains a socio-economic analysis and a critical bibliography. The social aspects of industrialisation in British territories in East and Central Africa are discussed by Merran MacCulloch; A. Hauser has dealt with the rural areas of French East Africa, and a report on the industrialisation of rural areas in Ghana has been prepared by Mrs. B. M. Niculesco. A review of the various studies has been made by Mrs. A. Chiva-Deluz.

\section{Socio-Economic Research in the Cameroons}

A RESEARCH team from the West African (now the Nigerian) Institute of Social and Economic Research is completing a study of sociological and economic problems associated with the presence of a large labour force working on the plantations in the southern areas of the territory. Dr. E. W. and Mrs. Ardener have investigated the tribal origins of the labour force and studied their family life, housing conditions, education, and religion. Dr. Ardener also made a detailed study of the indigenous inhabitants of the plantation area with particular reference to the decline in numbers, instability of marriage, and alleged shortage of land. He then made a brief survey of the areas in Nigeria and British Cameroons from which the plantation workers originate, analysing the rate of migration from different areas and its social effects. In addition he made a more detailed study of the Esu tribe in Bamenda Province which has a very high rate of migration. A fuller study of the Banyang tribe-one of the oldest sources of plantation labour-was contributed by Mr. M. J. Ruel. The other member of the team, Mr. W. A. Warmington, concentrated his study on the labour 
force of the Cameroons Development Corporation, analysing the reasons for high labour turnover, high rates of absenteeism, low productivity, \&c. In the course of this investigation he made studies of diets and nutrition, expenditure patterns, and employment histories.

The first report of the investigation, Economic, Labour and Social Aspects of Plantations in the Cameroons, includes an Introduction by its director, Professor Richardson of Leeds University, and six sections concerned with the economic and sociological background of the labour force, nutrition and expenditure, labour problems of the Development Corporation, the supply of labour, and a study of the indigenous peoples of Victoria Division with special reference to the impact of the plantation system on the local Bakweri and other peoples in regard to agriculture, land, and social problems.

\section{Cartes démographiques de l'Afrique}

Sous l'égide du Comité interafricain des Sciences humaines (CCTA/CSA), s'est tenue à Bruxelles, les 5 et 6 juillet 1956, une réunion de géographes, présidée par le professeur Gourou et consacrée à l'élaboration de cartes de densité et de distribution de la population de l'Afrique au Sud du Sahara. Une quinzaine de délégués représentant les territoires belges, portugais, anglais, sud-africain et français confrontèrent leurs méthodes et leurs réalisations et adoptèrent le plan de travail dressé par le professeur Gourou.

Deux séries de cartes sont prévues: la première, au $\mathrm{I} / \mathrm{r} .000 .000$, teprésentera la distribution de la population par points, sur la base d'un point par 100 habitants. La seconde, au I $/ 2.000 .000^{\circ}$, sera tirée de la première et mettra en valeur les zones de densité par un choix de teintes appropriées.

De nombreux problèmes techniques sont ainsi posés, en particulier la collecte d'une documentation de base exacte à l'échelle administrative la plus basse (c'est-à-dire pour les territoires français, le canton) et la localisation des points de distribution dans un pays où le peuplement même sédentaire est encore instable.

L'IFAN participera activement à une telle œuvre. D'ailleurs la section de géographie, poursuivant la parution des cartes ethno-démographiques, achève la préparation de la carte $\mathrm{n}^{\circ} 2$ qui couvre le Soudan occidental, les moitiés orientales de la Guinée française et de la Sierra Leone et le Libéria.

\section{La Conférence de l'O.M.S. pour l'Afrique au sud du Sahara}

LA sixième session du Comité de l'Office Mondial de la Santé pour l'Afrique au sud du Sahara, tenu en 1956 à Saint-Paul de Loanda, capitale de l'Angola, a consacré ses cinq journées de travail à l'étude du budget de l'O.M.S. et à la discussion de l'orientation à donner à l'action de l'O.M.S. en Afrique Noire.

La session, qui s'est deroulée sous la présidence du Dr Jorge Janz, professeur à l'Institut de Médecine tropicale de Lisbonne, et du Dr Dupré-Leroux, secrétaire d'État à la Santé d'Afrique du Sud, a décidé de porter en 1957 et en 1958 l'effort sur la lutte contre la lèpre et la tuberculose en Afrique. Cette campagne fait suite à celle menée en 1956 contre le paludisme et les trépanématoses. Selon les rapporteurs, la tuberculose se développe surtout dans les faubourgs ouvriers des grandes villes, et atteint deux fois plus d'hommes que de femmes. Dans les campagnes, la tuberculose semble due avant tout à la malnutrition.

C'est dans le domaine de la lutte contre la lèpre en A.É.F. que les résultats sont les meilleurs avec 120.000 cas dépistés, I 16.000 traités, sur un total de malades évalué à 150.000 .

Le sixième Comité de l'Office Mondial de la Santé pour l'Afrique Noire a décidé de tenir sa prochaine réunion - en septembre I957--à Brazzaville et sa session de 1958 à Monrovia. 